\title{
Challenges, Experiences and Opportunities of Water Resource Management in Ethiopia
}

\author{
Israel Koyra Merkineh Mesene \\ Wolaita Sodo Univerisity, NaRM Dep’t, PoBox-138
}

\begin{abstract}
Water is the basis of life and is a driving force for economic and social development and for poverty reduction. Eventhough Ethiopia has an abundant water resources, the country faces challenges in efficiently developing and managing its water resources (unevenly distributed). Between 80-90 percent of Ethiopia's water resources is found in the four river basins namely, Abay (Blue Nile),Tekeze, Baro-Akobo, and Omo-Gibe in the west and south western part of Ethiopia where the population is no more than 30 to 40 percent. The water policy of Ethiopia provides a conducive environment for having clean and safe water, by giving domestic water supply the highest priority followed by water for livestock. In the past, the absence of a well-defined water policy has been one of the major causes, for the poor performance of water development. The management of water as a critical resource should be done in a sustainable manner taking into account the needs of the present and future generations. In this respect, sustainable management of water resources should take into consideration the principles that water resources management should be decentralized, participatory and community based and conducted at the lowest appropriate level. It is also recognized that women play a central part in the provision, management and safeguarding of water resources and should be represented in decision-making process with regard to water resources management. There is a need to continue to develop its water resources in order for its economic and social development to keep pace with its rapidly growing population. Towards this goal the management approaches and organizational arrangements need to be reviewed to address the critical issue of water resource management.
\end{abstract}

Keywords: water resource, Ethiopia, management, opportunity, challenges

DOI: $10.7176 / \mathrm{JRDM} / 62-01$

Publication date: January $31^{\text {st }} 2020$

\section{Introduction}

Water is the basis of life and is a driving force for economic and social development and for poverty reduction. The provision of adequate supply of potable water in urban areas in both developed and developing countries is essential for life. For instance, in developing countries the provision of adequate potable water supply in addition to drinking and cleaning, improves health by reducing incidence of water-related illness such as diarrhea and cholera (WHO, 1995).

Ethiopia is the second most populous country in sub-Saharan Africa, with an estimated population of over 77 million. In order to meet the food needs of its rapidly growing population, the country needs to double the production of its cereal production by 2025 (IWMI, 2007). Agriculture is the largest sector of the economy contributing about $50 \%$ of the country's GDP and employing over $85 \%$ of the population. Agriculture in Ethiopia is mostly based on rain-fed small holder system (IWMI, 2005).

Although the Ethiopian agriculture is basically rainfall based, the country is endowed with vast water resources including 12 major river basins and 22 natural and artificial lakes. Considering both the available on surface water resources and the annual run-off amount, it was estimated that there would be about $1707 \mathrm{~m} 3$ water /person/year available (Ibid,2001).

Rainfall in Ethiopia is characterized by high spatial and temporal variability. Moreover, land degradation, mostly soil erosion, deforestation and overgrazing is high and is one major cause of declining crop and livestock productivity in the country. The challenge the country is facing is how to meet the increasing food demand with the existing but dwindling natural resource base under worsening climatic conditions. It is important to apply the right agricultural practices and management systems in order to increase agricultural productivity and production. Irrigation development in Ethiopia has been focused on the agronomic, engineering and technical aspects of water projects, with little consideration to issues of management, beneficiary participation and availability of institutional support services. Moreover, in many developing countries the success of irrigation systems is highly affected by policy, institutional and social factors much more than technical issues (Gebemedhin and Peden, 2002).

Sustainability of the management of water supply schemes is also a challenge for the sector. Poor coordination among stakeholders is aggravating the situation and constraining the economic returns on investment (Rodeco, 2002). In order to address these problems, effective management of water resources is essential for sustainable growth and poverty reduction. Water resources have been one of the most important areas of concern during the past three decades. Since the turn of the 20th century, the utilization of fresh water for economic purposes has posed a big challenge (Arsano, 2007). 
The overall objective of the paper is to make a review on the Challenges, Experiences and Opportunities with regard to the water resources management in Ethiopia.

\section{Result and Discussion}

\section{Water Resources of Ethiopia}

Surface Water Resources: River Basins

The country has 12 river basins. The total mean annual flow from all the 12 river basins is estimated to be 122 BMC. This could be further refined when data on recent master plan studies becomes available. Figure 1 below shows the map of Ethiopian River Basins. At present, surface water and meteorological data are collected and processed on a regular basis through existing hydro-meteorological networks. The idea of a river basin, despite its physical or natural attributes, is more than an engineering concept and encompasses the magnitude and dynamics of a resource that must be harnessed for the common good (Molle,2006).

Table 1. Ethiopian surface water resources by major river basins.

\begin{tabular}{|l|l|l|l|l|l|}
\hline No & River basin & Catchment area $\left(\mathrm{km}^{2}\right)$ & $\begin{array}{l}\text { Annual runoff } \\
\left(\mathrm{x} 10^{9} \mathrm{~m}^{3}\right)\end{array}$ & $\begin{array}{l}\text { Specific discharge } \\
\left(\mathrm{Litre} / \mathrm{km}^{2}\right)\end{array}$ & Share of total \\
\hline 1 & Abay & 199,812 & 52.6 & 7.8 & $43.05 / 17.56$ \\
\hline 2 & Awash & 112,700 & 4.6 & 1.4 & $3.76 / 9.9$ \\
\hline 3 & Baro-Akobo & 74,100 & 23.6 & 9.7 & $19.3 / 6.51$ \\
\hline 4 & GenaleDawa & 171,050 & 5.88 & 1.2 & $4.81 / 15.03$ \\
\hline 5 & Mereb & 5,900 & 0.26 & 3.2 & $0.21 / 0.52$ \\
\hline 6 & Omo-gibe & 78,200 & 17.96 & 6.7 & $14.7 / 6.87$ \\
\hline 7 & Rift valley & 52,740 & 5.64 & 3.4 & $4.62 / 4.63$ \\
\hline 8 & Tekeze & 90,000 & 7.63 & 3.2 & $6.24 / 7.9$ \\
\hline 9 & Wabishebele & 200,214 & 3.16 & 0.5 & $2.59 / 17 / 59$ \\
\hline 10 & Danakil & 74,000 & 0.86 & 0 & $0.7 / 6.5$ \\
\hline 11 & Ogaden & 77,100 & 0 & 0 & $0 / 6.77$ \\
\hline 12 & Aysha & 2,200 & 0 & 0 & $0 / 0.19$ \\
\hline & Total & $1,138,016$ & 122.19 & - & - \\
\hline
\end{tabular}

Ground water resource potential is approximately 2.6 billion cubic metres.

Source: Different master plan studies.

It has often been advocated that the most logical unit for water resources planning and optimum utilization of available water resources is the river basin. Accordingly, it is desirable that all major river basins in Ethiopia have an integrated development master plan, and their potential in terms of economic development be known (Lemma Gonfa, 1996 ).

Figure 1. Ethiopian river basins map

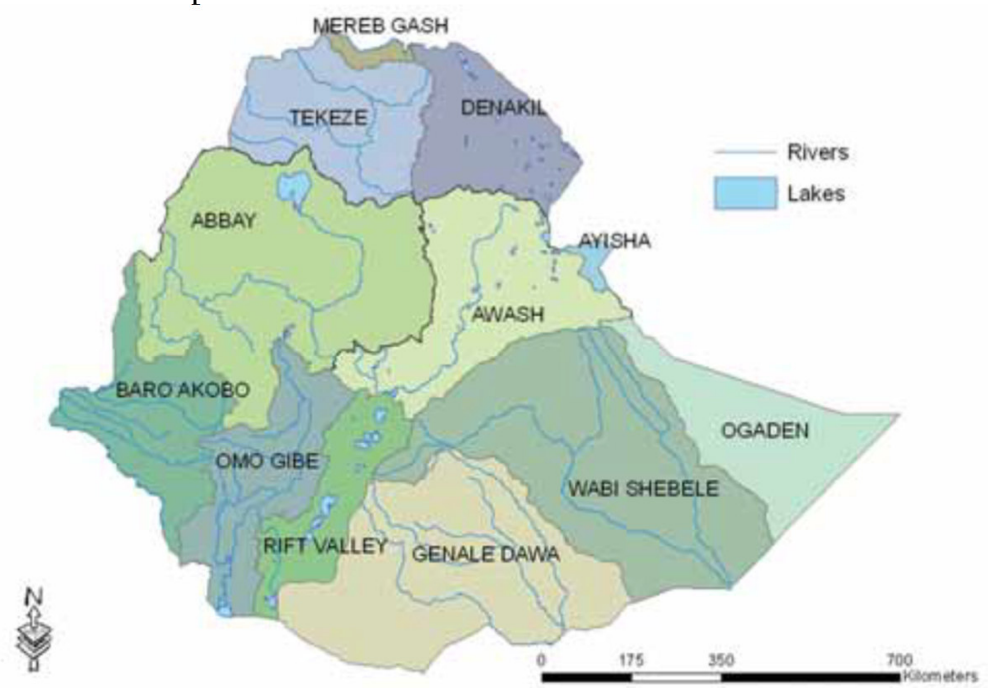

Source: Integrated River Basin Master Plan Studies, carrried out during 1997-2007 (MoWR 1996, 1997, 1998a)

\section{Surface Water Resources: Lakes and Reservoirs}

Ethiopia has 11 fresh and 9 saline lakes, 4 crater lakes and over 12 major swamps or wetlands.

Majority of the lakes are found in the Rift Valley Basin. The total surface area of these natural and artificial lakes 
in Ethiopia is about 7,500 km2. The majority of Ethiopian lakes are rich in fish. Most of the lakes except Ziway, Tana, Langano, Abbaya and Chamo have no surface water outlets, i.e., they are endhoric. Lakes Shala and Abiyata have high concentrations of chemicals and Abiyata is currently exploited for production of soda ash (Lemma Gonfa, 1996 ).

\section{Groundwater Resources System}

As compared to surface water resources, Ethiopia has lower ground water potential. However, by many countries' standard, the total exploitable groundwater potential is high. Based on the scanty knowledge available on groundwater resources, the potential is estimated to be about 2.6 BMC (Billion Metric Cube) annually rechargeable resource; which provides a little higher value (Yilma and Donkor, 1997).(Tadesse, 2004) estimated that at least 13.2 billion $\mathrm{m} 3$ infiltrates into the groundwater system of which 50 percent could be extractable.

\section{Water Resource Management}

\section{Nature of water management and value of water in Ethiopia}

The country has rainfall which varies in space and time. There is abundant water resources, but unevenly distributed. In addition to the above, the absence of a well-defined water policy has been one of the major causes, in the past, for the poor performance of water development. The Government of Ethiopia formulated and issued a comprehensive Water Resources Management Policy in 1999(FDRE, 2000:14).

According to the World Bank (1995) policy paper, "Water resource management that follows the principles of comprehensive analysis, opportunity cost pricing, decentralization, stakeholder participation, and environmental protection and investments across sectors, promote conservation, and improve the efficiency of water allocation" (World Bank, 1995:27). IWRM is concerned with the management of water resources, demand and supply (Global Water Partnership (GWP), 2000). In this regard, it is possible to achieve sustainable water resource use through a holistic multi-disciplinary approach. "The need for IWRM arises from regular interactions, uses and interests of interdependent groups that converge around a uniform whole" (GWP, 2000:17).

Fig.2:- Water resource management

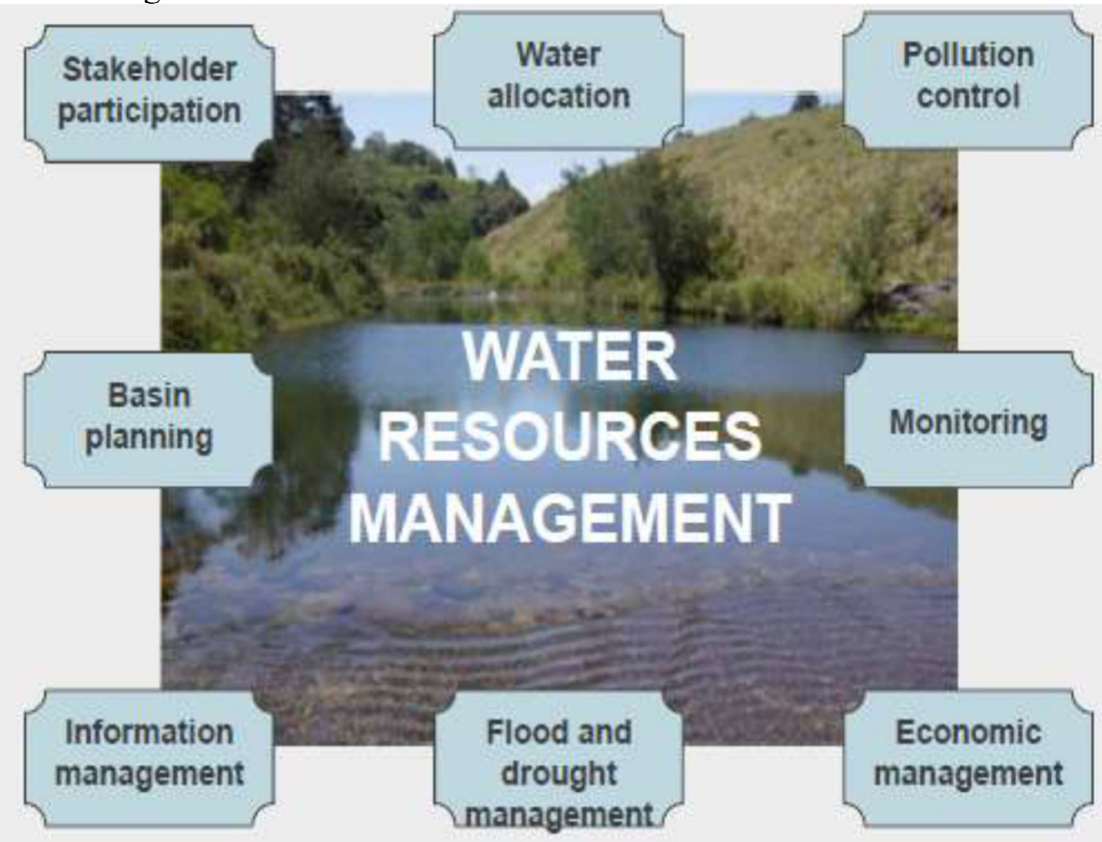

Source:- State of Ethiopia water resource management (2002) 
Fig. 3:- Water Resource Management Issues in Ethiopia

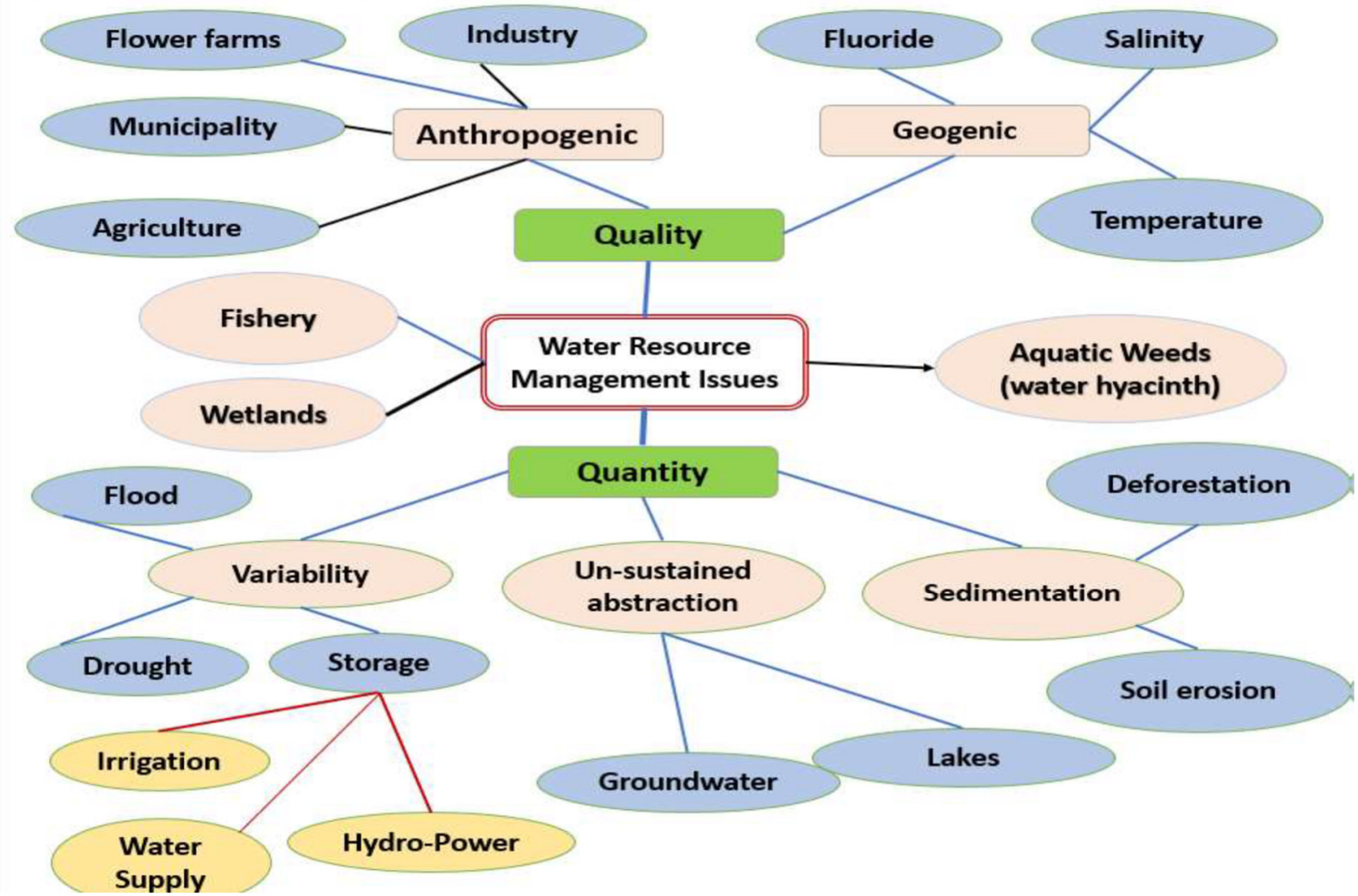

Source:- State of Ethiopia water resource management master plan (1997-2002)

Integration ensures respect and consideration of the needs and interests of each stakeholder. The challenge is to regulate water resources use to ensure sustainable and equitable use among various groups. The general objective of IWRM is to promote in an environmentally sound, equitable and sustainable manner the utilization and development of water resources. At the international Conference on Water and Environment held in Dublin January (UN, 1992b) also recognized the importance of IWRM and proposed that direct attention should be paid to the following six areas. These were namely the following:- 1. Integrated water resources development and management 2. Water resources assessment and protection of water resources 3 . Water quality and aquatic ecosystems 4. Drinking water supply and sanitation 5. Water and sustainable urban development, and 6. Water for sustainable food production and rural development. In the absence of the proper management of water, conflicts within countries often arise from competing water uses, and from overlapping and competing jurisdictional mandates of agencies dealing with water issues (Yilma and Donkor, 1997).

An integrated approach has therefore important institutional dimensions that would help to avoid conflicts related to water management. Continuing water scarcity that is experienced in most sub-Saharan countries necessitates the adoption of IWRM approaches (UNFPA, 1999).

In these premises the integrated approach to dealing with them is critical. Integrated Water Resource Management (IWRM) is attempting to meet all interests of various stakeholders and to coordinate them. Department of Water Affairs and Forestry (DWAF) (1996: 18) stated that: The conceptual basis of integrated catchment management relies on recognition that the different components of the hydrological cycle are intimately linked to one another and each component is affected by changes in every other component. Therefore, they cannot be managed effectively as separate or disconnected units. The water resources planners of a region must ignore the political boundary to harness and explore the resources in an integrated manner, making sure that it strikes a balance between the drinking, agricultural, fisheries, navigational and environmental needs, not only for the nation, but most optimally for the region (Ahmad, 2003).

Therefore, water resources in the watershed should be managed in a holistic manner. Projects in watershed management now have ultimately been linked to the sustainable development framework of local level focus. The goal is to establish a participatory water management environment with establishment of institutional structures at all levels to monitor the functions of the programmes. The guideline emphasizes local participation in the design and implementation of the programmes (Baumann, 1998). The holistic and participatory approach to catchment management developed in India is important and very relevant to the Ethiopian water resource management context. Given that decentralization is an important issue in the management of Ethiopian water resources, cognizance needs to be taken of the Indian approach. In this regard, there is a need for the establishment and 
maintenance of appropriate institutional structures for the management of resources. It is argued that water resource management entails not only an understanding of issues pertaining directly to standing and flowing water, but also an understanding of issues pertaining to the management of the entire catchment. Therefore, the IWRM approach argues that there is a fragmentary approach to water resources management and is one of the challenges hindering water resource development in Ethiopia. For this issue the best solution is a holistic approach to integrated water resources management (UNESCO,2008).

\section{Experience of Ethiopia Water Resource Management Policy}

Ethiopian Water Resources Management Policy emphasizes water for irrigated agriculture. Comprehensive water management involves a number of functions that are closely related but which are carried out by different agencies and organizations. The functions include water law and policymaking, regulation, technical assistance and coordination, monitoring and evaluation, administration and financing, public education and involvement (MoWR, 1999).

The general water resources policy among many others include: enhancing integrated and comprehensive management of water resources that avoids fragmented approach. Recognizing that water resources development, utilization, protection and conservation go hand in hand and ensure that water supply and sanitation, irrigation and drainage as well as hydraulic structures, watershed management and related activities are integrated and addressed in unison. Recognizing water as scarce and vital socio-economic resource, manage water resources as strategic planning basis with long-term visions and sustainable objectives. It ensures that water resources management is compatible and integrated with other natural resources as well as river basin development plans, with the goals of other sectoral developments in health, mines, energy and agriculture, etc. As the fundamental planning unit and water resource management domain, the strategy recognizes and adopts the hydrologic boundary or basin. It also ensures that all planning, studies, programs and development objectives in the water sector include protection and conservation, operation and maintenance as well as replacement activities and budgets. It also promotes and encourages that conservation of existing water systems and efficient utilization of water is as feasible as development of new schemes (Mokuoane E. ,2000).

\section{Water Usage in Ethiopia}

Though the country possesses a substantial amount of water resources, little has been developed for drinking water supply, hydropower, agriculture and other purposes. The water supply coverage was estimated to be 30.9 percent, thus the rural water supply coverage being 23.1 percent and that of urban being 74.4 percent (UNESCO, 2004).

The great majority of the rural Ethiopian population community water supply relies on groundwater. The safe supply of water in rural areas is usually derived from shallow wells, spring development and deep wells. People who have no access to improved supply usually obtain water from rivers, unprotected springs, hand-dug wells and rainwater harvesting. Based on the present indicative information sources, the potential irrigable land is about 3.7 million hectares. Section "Irrigation Potential in River Basins of Ethiopia", is fully devoted to the irrigation potential of Ethiopia. The area under irrigation development to date, obtained from different sources is estimated to range between 160,000 - 200,000 hectares. At present some 197,000 hectares of land is under irrigation Solomon 2006. Estimates of the irrigated area presently vary, but range between 150,000 and 250,000 hectares less than five percent of potentially irrigable land (Werfring, 2004; Awulachew et al., 2005).

In this project, we have developed a database, as a starting point of shared information. Estimates of the irrigated area according to this database (based on the data reported by the MoWR), is 107,265.65 hectares, which is less than 5 percent of the potential. This database does not contain schemes which are under construction, or inoperational /suspended for some reasons. Details of the irrigation development are provided in the section "Irrigation Development in Ethiopia". Constraints of Water Resources Development in Ethiopia are numerous. They fall in one of the general categories of legal, political, social, institutional or technical. These require careful consideration and need to be supported by applied research if the required level of development is to be ensured. Increasing the role of applied research is one of the means to alleviate the problems encountered in the water sector. Irrigation and drainage research is considered as part and parcel of water resources research. Significant research activities have not yet been undertaken on irrigated crops. This is because, unlike the agricultural and health sectors, institutionalized water research in Ethiopia does not exist, as it is the case in most parts of Africa and underdeveloped countries (Easter et al., 1997).

According to Easter et al., (1997), where water is becoming scarce, it is desirable to discourage low-value uses. Where users have entrenched rights to water supply, reallocation is only possible if they can be encouraged to sell some of their water to others presumably for higher-value purposes (Winpenny, 1994).

The possibility of reallocating water to high-value purposes should be investigated as an alternative to, or in parallel with, developing new sources of supply; in this context the use of water markets can be appropriate. Others however, argue that the introduction of water marketing and pricing would violate human rights (Bakker, 2001).

Recent reviews of the basin-wide approach designed primarily on hydro geological rather than administrative 
boundaries, could provide the basis for pursuing an integrated approach to water resource management and for solving regional and sectoral conflicts (Easter, 1999).

The proponents of water economics explain that water scarcity could easily be solved with market instruments because it is a renewable and reusable resource. It also places emphasis on the majority of poor people in developing countries like Ethiopia who do not have access to clean and safe drinking water. In Ethiopia, the official documents and legal frameworks increasingly view water as a scarce commodity (as an economic good) shifting from the previous social good concept. This shift is conspicuously placed in the Dublin Principles, the World Water Council and Global Water Partnership documents ( (MoWR), 2001a).

The percentage of the Ethiopian population with access to safe and clean drinking water remains almost stagnant below 65 percent overall. In urban areas it is 94 percent, and 56 percent in rural areas (CSA and ORC, 2005).

The establishment of a legal institutional framework on shared water resources is essential, because upstream and downstream water users will have a guarantee to use the water efficiently.

In Ethiopia the need to develop a method of integrated river basin approach has been recognized. This is evident given the provisions in the Ethiopian Water Resource Management Policy (1999) responsible for legislation with regard to the utilization and protection of water resources as well as the sustainable management and allocation of water between regional governments. Within the emerging framework of demand responsive approaches, the role of government is changing from service provision to facilitating and providing an enabling environment (UN-WWAP, 2006).

Effective river basin management is essential for sustainable growth and poverty reduction; to protect loss of ecosystem and biodiversity; to reduce loss of life from floods; and to provide improved drinking water services for local communities (UN-WWAP, 2006). This results in creating strong inter sectoral allocation of water that enable sufficient supplies for irrigation, hydro-electric, municipal water supply and ecosystem maintenance. The government is being made an attempt to develop additional Hydro-Electric Power (HEP) project along Omo River. Such attempts include the development of Gilgel Gibe HEP Project which has led to the construction of three phases of dam generation of 2474 Mega Watt (MW) along Omo River in the Southern Ethiopia. The Gilgel Gibe project level I produces $184 \mathrm{MW}$ (completed) and level II produces $420 \mathrm{MW}$ and is close to be completed while level III is under construction. When completed, it is estimated that 1870 Mega Watt of power can be produced, which is expected to supply power beyond the demands of the country and for regional countries, such as Kenya, Sudan, and Djibouti (The Reporter, 2009). The hydropower potential of these reservoir sites is the most significant aspects of water resource development in Ethiopia, since per-capita energy consumption and access to safe water supply in Africa is among the lowest in the world (The Reporter, 2009).

\section{Water-demand approach}

This approach has been included here in order to assess its usefulness in explaining issues of water use and management and to illustrate the shift to a demand-side approach. The conventional paradigm of water/wastewater management has been characterized as supply-driven, centralize-d and large-scale. This approach has led to the over-exploitation and depletion of renewable water resources, the mining of non-renewable groundwater resources and the deterioration of water supplies (Rahmato, 1999).

As water is vital to life, people will always be willing to pay user fees in order to access water. However, if user fees for water tend to absorb disproportionate amounts of household incomes, in previously marginalized communities, the privatization of water will only serve to further exacerbate existing trends of power differences between various people and/or communities. "In contrast to the public sector monopoly of water utilities that, ultimately, aims for universal access, private sector suppliers rely on a narrower financial cost-benefit analysis geared towards cost-recovery and maximizing profit in a market setting" (Taylor, 2004).

This approach however, neglects the negative externalities that stem from excluding access to those who are unable to pay fees for water. Moreover, "the new approach extends to management through 'degoverning' that is using the market as a mechanism of governance through privatization and commodification of public goods" (Narsiah, 2010).

\section{Challenges of Ethiopia Water Resource Management Policy Finance and Economics}

One of the most challenging areas of the policy is finance and economics. As a tradition, water is considered simply as a natural resource and even most of the people may not be aware of its economic value. On the contrary, the investment requirement of water is high while the time requirement to get returns is long. Even some of the outcomes from providing water are not also easily understood, which complicate water pricing (World Bank,1996).

Unless there is some justification (social or political), any investments made must be paid back, which is also the direction of the water policy. The policy and strategy provisions address the issue of cost recovery and water pricing. Urban water supply and irrigation projects are required to cover investment, operation and maintenance 
costs. Rural water supply projects are only required to cover the cost of operation and maintenance. Water pricing is done in order not to harm the beneficiaries and yet discourage misuse of the resource (Rahmato, 1999).

These problems can be considered as challenges in providing quality water to its residents. Water scarcity, power interruption, rapid urbanization, changing living conditions, pipes and valves are major challenges, whereas unmonitored waste disposal and private ground water exploration, exposing water to pollution, unplanned land use, requiring hugein vestment to control and improve water quality, rapid growth of population, environmental degradation and weak and inefficient water resource management are the main issues that need urgent solution for the efficient and sustainable use of water resources to address the problem of access to clean water supply for the urban poor in Addis Ababa (Rahmato,1999).

All the above mentioned problems are the result of poor water resource management practices. For example, the operators pay a subsidized rate, which is the lowest rate in the tariff block, but are charging a tariff rate which is far higher than the highest rate set for private connections. This is related to Hardoy and Satterthwaite's (1997) observation that informal water traders get subsidized rates for purchasing water and this subsidy is rarely reflected in prices charged to the poor by water vendors. Arguably, this is contrary to the water resource management policy of Ethiopia that proposes subsidized tariff rates for communal water services. Therefore, there is a need to adopt a water demand management strategy in Addis Ababa Water and Sewerage Authority, as the narrow supply oriented approach is not efficient in the management of water supply and does not satisfy the demands of the urban poor in economic, social and environmental terms. Supply-side management of water resources are unable to provide adequate quality water to poor urban areas of low income households (Marvin and Laurie, 1999).

It can be argued that IWRM might be considered as the means to resolve complex environmental problems caused by anthropogenic sources. The underlying causes of deforestation, critical watershed and land mismanagement are those factors which may create an environment where further imbalance between water supply and demand, water pollution, flood and drought as well as erosion and sedimentation can occur (Islam, 2012).

\section{Future opportunity of Ethiopia Water Resource Management}

Water quality is a critical issue in a number of areas, including the groundwater in the Rift Valley basin, which is high in fluorides. In other areas, iron deposits are problematic. The lack of information on water quality makes it difficult to determine appropriate strategies in a particular locality. Despite its importance to water management, there is limited water quality monitoring in Ethiopia. Upstream activities in a number of basins are polluting the water bodies with little consideration for stakeholders downstream. Without improved management, the situation will further deteriorate and could lead to conflict. Water allocation will also be another area of concern. So far, there is no major record of conflicts. Nevertheless, there are some cases, such as the issue of abstraction and pollution by upstream residents, which beneficiaries have started to complain about. This is actually an international phenomenon that relates with population growth and resource scarcity (Abernethy, 2000).

For Ethiopia, which has an economy highly dependent on agriculture and high population growth, it is prudent to effectively manage its water resources, build capacity and link development efforts with practical research findings. Development efforts made so far were not supported by empirical research findings; rather they have relied on theoretical ideas or imported experience, which do not fit the prevailing conditions on the ground. The (EWRMP) that was developed in 1999 attempted to address all the issues highlighted above (MoWR, 1999).

The policy is detailed on various issues, including research. However, since the document is holistic in nature, there are certain issues still to be examined at a local level. Some of the relevant parts of the policy will be presented later when the development approach is discussed. The sector strategy also addressed the issue of research as one of the important inputs to the success of the water sector programme implementation. Water is a source of life regardless of its location, culture or ownership. That is why it remains a source of conflict and suspicion for some countries. Of course, there are cases where countries have been able to manage their shared water and mutually use it (Mokuoane, 2000). Since $75 \%$ of the rivers that originate in the highlands of Ethiopia cross the border and feed neighboring countries, co-operation is not only important but a must. That is why the Ethiopian Government in its water resources policy had made its commitment clear towards the principle of equitable and reasonable use of water resources. International efforts and the policy direction have brought together the partners in the Nile basin under the umbrella of the Nile Basin Initiative (NBI). It is clear that this is a start of a long journey, which could collapse at any time unless otherwise supported by all the necessary instruments, including empirical research results on the benefits that could be achieved from the co-operation and the mechanisms to strengthen it. Capacity building and dialogue among all stakeholders have to continue to facilitate research and co-operation. With respect to Ethiopia, which contributes about $86 \%$ of the Nile waters and the sources of other trans-boundary rivers, the lack of capacity both at regional and national levels is evident. Without improved management, the situation will further deteriorate and could lead to conflict. Water allocation will also be another area of concern. So far, there is no major record of conflicts. Nevertheless, there are some cases, such as the issue of abstraction and pollution by upstream residents, which beneficiaries have started to complain about. This is actually an international phenomenon that relates with population growth and resource scarcity (Abernethy, 2000). 


\section{Conclusion}

The big and main water resources problem in Ethiopia is uneven spatial and temporal occurrence and distribution. Between 80-90 percent of Ethiopia's water resources is found in the four river basins namely, Abay (Blue Nile),Tekeze,Baro-Akobo,and Omo-Gibe in the west and south western part of Ethiopia where the population is no more than 30 to 40 percent.

The people of Ethiopia have the fundamental right to have access to potable water supply. Since there are several demands for water, and at the same time water is being unevenly distributed in the country, there is a need for fair, equitable and sustainable access to clean water. The water policy of Ethiopia provides a conducive environment for having clean and safe water, by giving domestic water supply the highest priority followed by water for livestock (MoWR, (2002)).

According to Laurie and Crespo, (2007) "We cannot live without water; therefore water cannot be a private business ... (because) it violates human rights. Water must be a public service; it is not possible to privatise the basic services, particularly water and sanitation".

Ethiopia faces challenges in efficiently developing and managing its water resources. The management of water as a critical resource should be done in a sustainable manner taking into account the needs of the present and future generations. In this respect, sustainable management of water resources should take into consideration the principles that water resources management should be decentralized, participatory and community based and conducted at the lowest appropriate level. It is also recognized that women play a central part in the provision, management and safeguarding of water resources and should be represented in decision-making process with regard to water resources management (Gebrehiwot, 2007).

Ethiopia faces challenges in efficiently developing and managing its water resources. There is a need to continue to develop its water resources in order for its economic and social development to keep pace with its rapidly growing population. Towards this goal the management approaches and organizational arrangements need to be reviewed to address the critical issue of water resource management (Rahmato, 1999:76).

\section{References}

Abernethy C.L. (ed). 2000. Inter-sectoral management of river basins. Proceedings of an international workshop on integrated water management in water stressed river basins in developing countries: Strategies for poverty alleviation and agricultural growth, held in Loskop Dam, South Africa, 16-21 October 1999.Pretoria, South Africa.

Admassu Gebeyehu. 1996. Assessment of crop production and vulnerability to famine. Case study of Wello in 1994.

Arsano, y. (2007). Ethiopia and the Niles dilemmas of national and regional hydroponics,Centre for security studies, swiss federal institute of technology, zurich, Switzerland.

Easter, k. (1999). The transition of irrigation management in Asia: have we turned the corner yet?

FDRE.2000. Ethiopian Water Resource Management Proclamation No. 197/2000. Berhanena Selam Printing Press, Addis Ababa, Ethiopia.

Gebrehiwot, M. (2007). Gender Mainstreaming in Forestry in Africa Ethiopia. FAO, Rome.

Islam, K.K.; Sato, N. Deforestation, land conversion and illegal logging in Bangladesh: The case of the Sal (Shorea robusta) forests. I Forest 2012, 5, 171-178.

Lemma Gonfa, 1996. Climate classification of Ethiopia. MoFED. 2002. Ethiopia: Sustainable development and poverty reduction program.

Mokuoane E. 2000. The Danube River basin: International cooperation in water management.

Kessides,Christine.1993. Institutional Options for the Provision of Infrastructure. World Bank Discussion Paper 112. Washington, D.C.

Kirmani, Syed, and Robert Rangeley. 1992. "International Inland Waters: Korton, F. F., and R. Y. Siy. 1989. Transforming a Bureaucracy: The Experience of the Philippine National Irrigation Administration. Manila, Philippines:

Kurup, K. Balachandra. 1991. "Participatory Strategies in Water, Health, and Rural Development Programmes." Waterlines 10 (2): 2-5.

Lee, T. R. 1990. Water Resources Management in Latin America and the Caribbean B. oulder,Colo.: Westview Press.

Marvin, s. \& laurie, N. (1999). An Emerging Logic of Urban Water Management, in Cochabamba, Bolivia. Urban Studies, 36 (2) 341-357.

Moses K. Tesi, 2000. The Environment and Development in Africa. Lexington Books, Murfreesboro, Tennessee, USA. 329 pages. MOWR, 2005. Koga Irrigation and Watershed Management Project: Koga Small Scale Irrigation, Rural Water Supply and Sanitation. Volume-I main report, Addis Ababa, Ethiopia. MoWR. 2002. Assessment and Monitoring of Erosion and Sedimentation Problems in Ethiopia. Final Report Volume V, MoWR/ Hydrology Department, Addis Ababa, Ethiopia. 
MoWR,(1999). Ethiopian Water Resources Management Policy.

MoWR,(2002). Water Sector Development Programme 2002- 2016.

Rahmato, D. (1999). Water Resource Development in Ethiopia: Issues of Sustainability and Participation, Forum for Social Studies, Addis Ababa.

UNESCO.(2008). The United Nations World Water Development Report, World water assessment program.

World bank. (1996). Measuring Economics Benefits for Water Investments and Polices.

WHO. (1995). A Review of the Operation and future development of the who healthy cities, programme, world health organization, Geneva.

Zewide, A. (1994). Water Resource Development In Ethiopia: An Evaluation of Present and future planning concepts; a management method for analysing a key resource in a nations development, ithaca press, reading, UK. 